\title{
ARTIKEL
}

\section{ANTARA PERPUSTAKAAN DAN GOOGLE IBARAT DUA SISI MATA UANG}

\author{
Djuwarnik, Prasetyo Adi Nugroho \\ Perpustakaan Universitas Airlangga \\ e-mail: djuwarnik@staf.unair.ac.id, prasetyo.adi@staf.unair.ac.id
}

\begin{abstract}
ABSTRAK
Perpustakaan dan google ibarat dua sisi mata uang yang tidak dapat dipisahkan dan keduanya saling berkaitan. Keduanya yaitu perpustakaan dan google adalah sama-sama sebuah pusat informasi. Google sampai tahun 2016 telah sukses memindai 30 juta dalam 480 bahasa. Google menyediakan berbagai macam informasi serta hiburan. Mulai dari pelajaran sekolah, film, musik, serta berbagai lainnya. Meskipun perpustakaan tidak dapat menyaingi keunggulan google paling tidak perpustakaan memfasilitasi kemudahan akses untuk memanfaatkan google. Peran perpustakaan dalam hal ini sangatlah penting, karena pustawakan mampu memberikan informasi yang relevan dari sumber yang terpercaya. Pustakawan adalah sumber informasi, kita bisa bertanya seputar kebutuhan yang membutuhkan bukti otentifikasi dari sebuah pernyataan yang akan kita buat. Seperti mata uang, Perpustakaan dan google bisa kita gunakan sebagai sumber referensi kita untuk mencari informasi.
\end{abstract}

Kata Kunci: Perpustakaan, Google, internet

\section{PENDAHULUAN}

Perkembangan teknologi informasi dan komunikasi semakin memudahkan orang dalam memenuhi kebutuhannya. Dengan hadirnya internet semakin memudahkan orang untuk terhubung satu sama lain seolah tanpa dibatasi jarak dan waktu. Internet telah menguasai kehidupan manusia di segala bidang. Kehadiran internet dianggap menjadi kompetitor bagi lembaga penyedia informasi termasuk perpustakaan. Kehadiran internet telah mengubah perilaku manusia. Pekerjaan yang awalnya dilakukan secara manual atau konvensional telah berubah menjadi serba online. Dalam menghadapi perkembangan ini sudah seharusnya perpustakaan mempersiapkan diri dengan cara berinovasi sehingga tidak ditinggalkan oleh pemustakanya. Perpustakaan harus memahami dan menyediakan kebutuhan masyarakat di era digital dengan melakukan inovasi-inovasi sesuai dengan perkembangan teknologi.

Di era digital sekarang ini perpustakaan bukan lagi menjadi satu-satunya pusat sumber informasi yang menjadi rujukan para pencari informasi seperti mahasiswa, dosen atau masyarakat umum. Seiring perkembangan teknologi informasi dan komunikasi (IPTEK) muncul pesaing terbesar dari perpustakaan yaitu google. Dengan menggunakan google orang dapat memperoleh segala macam informasi dengan mudah dan cepat. Dengan mengetikkan sebuah kata kunci atau cukup klik satu tombol maka informasi yang diinginkan akan segera muncul. Kita dapat memperoleh informasi apapun yang kita butuhkan hanya dalam hitungan menit, bahkan kapan saja kita menginginkan tanpa batas jarak, waktu dan ruang. Perkembangan teknologi yang cepat semakin memudahkan orang dalam memenuhi kebutuhannya.

Sebuah studi di Amerika Serikat, berdasarkan laporan dari The Pew Internet \& American Life Projects (2012) menunjukkan data pembaca e-book dan buku cetak. Berdasarkan gambar 1 menggambarkan sumber rekomendasi materi bacaan bagi pembaca e-book usia 16th keatas vs keseluruhan responden, menunjukkan rendahnya sumber bacaan dari perpustakaan ketimbang sumber online dari google.

Perkembangan IPTEK sempat menorehkan kekhawatiran terhadap dunia perpustakaan dan kepustakawanan. Dengan kecanggihan IPTEK tersebut masihkah perpustakaan dibutuhkan? Munculnya internet dan kecanggihan google hampir saja menggantikan peran dan fungsi perpustakaan sebagai pusat sumber informasi. Hampir semua informasi yang dicari oleh peselancar dunia maya bisa diperoleh melalui internet. Kecanggihan 


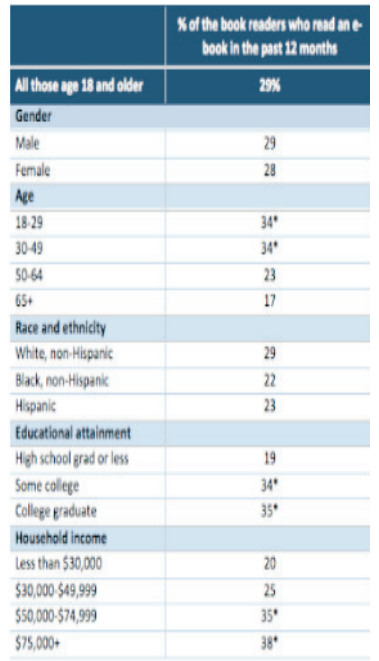

Gambar 1. Presentasi pembaca buku cetak dan online

internet inilah yang memunculkan kekhawatiran dunia kepustakawanan dan perpustakaan sebagai penyedia informasi.

Chandraleka (2014) dalam artikelnya yang dimuat dalam ilmukomputer.com menuliskan bahwa mencari di google lebih mudah, tidak perlu keluar rumah, bermacetmacet ria, berpanas-panasan, atau bahkan hujan-hujanan di jalan. Mencarinya juga cukup bermodal kata kunci yang sederhana. Kedua, kurang terperbaharuinya bukubuku di perpustakaan kampus. Masih saya jumpai banyak buku di perpustakaan kampus yang sudah lapuk di makan zaman,

Bagi perpustakaan yang menghargai inovasi, niscaya tidak dihadapi dengan tangisan, melainkan sikap produktif. Menjadi pustakawan produktif adalah kunci awal bertahan di tengah era inovasi yang disruptif ini (Wijayanti, 2017). Sebuah Perpustakaan yang tidak cepat berubah melalui kegiatan-kegiatan produktif maka akan tersisihkan. Pustakawan pun tidak akan bisa menolak perubahan karena sikap produktif adalah cara terbaik menghadapi perubahan. Oleh karena itu, dalam penulisan artikel ini, penulis ingin menggambarkan kolaborasi perpustakaan dan google dalam hal penyediaan sumbersumber informasi.

\section{KAJIAN PUSTAKA}

\section{Google}

Google berawal dari proyek penelitian dua mahasiswa Ph.D. Universitas Stanford, Larry Page dan Sergey Brin pada awal 1996 yang mengembangkan teori bahwa sebuah mesin pencari yang berdasarkan analisis matematika hubungan antara situs-situs web akan memberikan hasil yang lebih baik daripada dengan menggunakan teknikteknik pencarian dasar yang digunakan pada saat itu. Sistem ini pada awalnya dinamakan BackRub karena menggunakan backlink untuk memperkirakan seberapa penting sebuah situs. (Hamen, 2011: 6).

Google menjadi populer di antara pengguna Internet karena desainnya yang sederhana dan 'bersih' serta hasil pencariannya yang relevan. Iklan dijual berdasarkan kata kunci (keyword) sehingga mereka menjadi lebih relevan bagi para pengguna, dan iklan-iklan tersebut diharuskan menggunakan teks saja agar desain halaman tetap rapi dan loading halaman tetap cepat.

\section{Perpustakaan Perguruan Tinggi}

Perpustakaan Perguruan Tinggi adalah perpustakaan yang merupakan bagian integral dari kegiatan pendidikan, penelitian dan pengabdian pada masyarakat dan berfungsi sebagai pusat sumber belajar untuk mendukung tercapainya tujuan pendidikan yang berkedudukan di perguruan tinggi (PP RI Nomor 24 Tahun 2014 Pasal 1 angka 10).

Keberadaan sebuah perpustakaan perguruan tinggi begitu penting sebagai unsur penunjang dalam proses pembelajaran, penelitian dan pengabdian pada masyarakat sehingga perpustakaan perguruan tinggi diibaratkan sebagai jantungnya universitas. Dengan kata lain bahwa perpustakaan merupakan suatu organ vital yang harus dimiliki oleh lembaga pendidikan. Tanpa adanya perpustakaan maka suatu lembaga pendidikan akan statis (mati).

\section{METODOLOGI}

Kajian ini menggunakan metode kualitatif yang menghasilkan data berupa kata-kata tertulis dengan pendekatan deskriptif dengan memberikan gambaran penyajian berisi kutipan berbagai data. Selain itu dilakukan juga beberapa kajian teori mengenai google dan perpustakaan perguruan tinggi.

\section{PEMBAHASAN}

Di era digital ini, perkembangan perpustakaan tidak dapat terlepas dari perkembangan teknologi dan dampak perubahan hidup masyarakat (Patra, 2017). Dalam hal ini, perpustakaan perlu mengadopsi teknologi digital untuk menyediakan kebutuhan informasi pengguna, dan jika 
masih mempertahankan layanan konvensionalnya maka akan ditinggalkan oleh penggunanya, dan fenomena tersebut dapat mengakibatkan fungsi perpustakaan berkurang dan peran pustakawannya terdisrupsi (Khoir, 2018).

Selain itu, pustakawan juga perlu melakukan transformasi perannya. Fatmawati (2013) mengatakan bahwa transformasi peran pustakawan perguruan tinggi diperlukan dalam rangka mewujudkan layanan perpustakaan yang humanis, yang mencakup transformasi dari: (a) budaya lisan menjadi budaya tulis; (b) layanan perpustakaan berbasis sumber daya fisik menjadi berbasis pengetahuan; (c) layanan koleksi fisik (kertas) menjadi layanan elektronik/digital (paperless); (d) pengelolaan perpustakaan sendiri menjadi berkolaborasi; dan (e) paradigma ahli kepustakawanan saja menjadi ahli interdisipliner yang multidisiplin ilmu. Ketika tugas di perpustakaan, pustakawan dapat mensinergikan pengetahuan, konektivitas, dan komunitas dalam pemberian layanan referensi di perpustakaan (Vijayakumar \& Vijayakumar, 2003).

Pembahasan mengenai internet tidak bisa dilepaskan dengan google. Dimana untuk berselancar dalam internet dibutuhkan sebuah mesin pencari (search engine). diantara sekian banyak mesin pencari yang paling populer adalah google. Perpustakaan dan google ibarat dua sisi mata uang. Di tengah pesatnya perkembangan teknologi yang mungkin akan menjauhkan pemustaka dengan perpustakaan, pustakawan harus berkompromi dengan perkembangan yang terjadi. Meskipun perpustakaan tidak dapat menyaingi keunggulan google paling tidak perpustakaan memfasilitasi kemudahan akses untuk memanfaatkan google.

Melihat kondisi seperti ini, maka perpustakaan memperoleh tantangan dengan kehadiran google karena hampir setiap hari pemustaka mencari informasi melalui google hanya dengan mengetik satu kata kunci sudah bisa mendapatkan berbagai informasi. Pemustaka saat ini dihadapkan pilihan perpustakaan atau google. Satu sisi harus pergi ke perpustakaan untuk mendapat informasi yang terpercaya dan akurat sedangkan satu sisi harus pergi meng 'klik' ke Google dengan risiko informasi yang belum tentu akurat tetapi nilai plus yang menggiurkan yaitu cepat dalam penelusuran sebuah informasi meskipun belum tentu informasi yang tersedia di google dipercayai validitasnya karena berasal dari berbagai sumber.

Untuk mengantisipasi perkembangan yang terjadi berbagai inovasi bisa dilakukan oleh perpustakaan untuk memenuhi kebutuhan pemustaka. Lebih-lebih

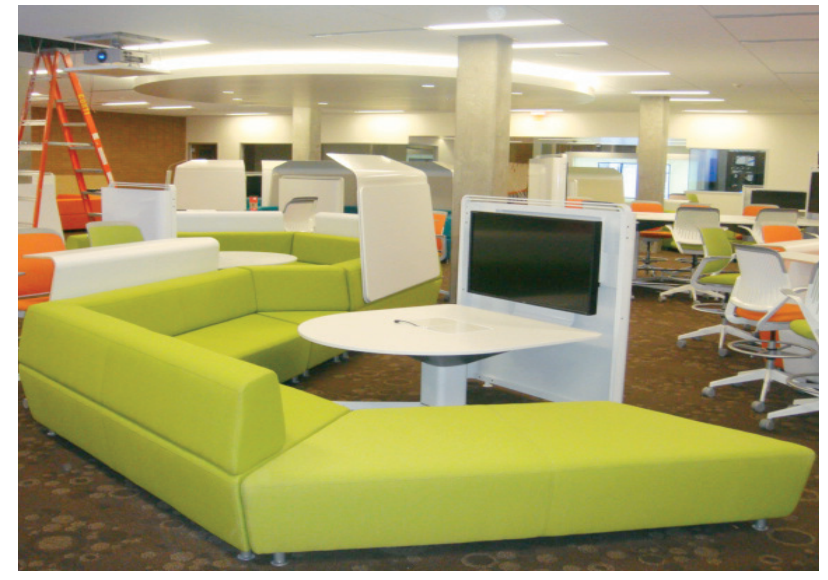

Gambar 2. Contoh ruang belajar instagramable di Perpustakaan

perpustakaan perguruan tinggi yang lebih beragam dan lebih besar tingkat kebutuhan pemustakanya.

Salah satu contoh inovasi di perpustakaan perguruan tinggi bisa melalui ruang belajar yang didesain sesuai selera anak muda, instagramable akan membuat pemustaka serasa berada di rumah sendiri. Suasana yang nyaman akan menjadikan perpustakaan sebagai rumah kedua bagi pemustaka.

Kenyamanan ruang perpustakaan akan menjadi daya tarik tersendiri bagi pengunjung perpustakaan. Suasana perpustakaan yang nyaman akan membuat pemustaka betah untuk berlama-lama berada di perpustakaan.

Perpustakaan akan selalu dikunjungi pemustakanya, dan koleksinya juga akan selalu dimanfaatkan oleh pemustakanya, jika informasi atau koleksi tersebut tidak tersedia di google dan informasi yang dimiliki oleh perpustakaan dapat memenuhi kebutuhan informasi para penggunanya.

\section{PENUTUP}

Perpustakaan dan google ibarat dua sisi mata uang yang tidak dapat dipisahkan. Perpustakaan bisa mengelola berbagai jurnal, beragam artikel dan beraneka karya ilmiah, yang dikemas menarik dengan bantuan google. Ibarat simbiosis mutualisme, keuntungan yang didapat perpustakaan membuatnya menjadi pelanggan setia google Istilah lainnya adalah google menawarkan bahan mentah pada menu-menunya, sedangkan kegiatan pengolahan menjadi barang siap pakai bagi pemustaka menjadi tugas dari perpustakaan. 


\section{DAFTAR PUSTAKA}

Chandraleka, H. 2014. Mending ke Google daripada ke Perpustakaan. IlmuKomputer.Com

Fatmawati, E. 2013. Transformasi Peran Pustakawan Perguruan Tinggi dalam Mewujudkan Layanan Perpustakaan Yang Humanis. Bunga Rampai Layanan Perpustakaan Berbasis Humanisme (Ed. Khoirul Maslahah \& Nushrotul Hasanah R.). Surakarta: Perpustakaan IAIN Surakarta.

Hamen, Susan E. 2011. Google: Company and Its Founders. New York, NY: McGraw-Hill, 2011.

Khoir, S. 2018. The Need to Change: Perilaku dan Manajemen Informasi dalam Era Normal Baru. Makalah Dies Natalis Ke-67 Perpustakaan Universitas Gadjah Mada pada hari ini 1 Maret 2018. Yogyakarta: Universitas Gadjah Mada.

Nugroho, Dicki Agus. 2018. Menjadi Pustakawan Produktif Di Era Disrupsi. Makalah seminar dan call for papers Perpustakaan Universitas Surabaya 20-21 Maret 2018. Surabaya, Ubaya, 2018.
Patra, N. K. 2017. Digital Disruption and Electronic Resources Manajemen in Libraries. Elsevier: Chandos Publishing.

Perpustakaan Nasional RI. 2014. Peraturan Pemerintah Republik Indonesia Nomor 24 Tahun 2014 tentang Pelaksanaan Undang-Undang Nomor 43 Tahun 2007 Teantang perpustakaan. Jakarta: Perpusnas, 2014.

Rainie, L., Zickuhr, K, Purcell, K, Madden, M. Brenner, J. 2011. The Rise of E-Reading. Pew Reseach Center's Internet American Life Reading Habits Survey.

Vijayakumar, J. K \& Vijayakumar, M. (2003). Knowledge, Connections, and Communities: A Special Reference to Indian University Libraries. International Information \& Library Review, 35, 375-382.

Wijayanti, Fitri. 2017. Menjadi Produktif di Era Inovasi Disruptif. http://www.koran-jakarta.com/menjadiproduktif-di-era-inovasi-disruptif/.Diakses 13 Februari 2018. 